\title{
Decadal changes in wave climate and sea level regime: the main causes of the recent intensification of coastal geomorphic processes along the coasts of Western Estonia?
}

\author{
Ü. Suursaar \& T. Kullas \\ Estonian Marine Institute, University of Tartu, Estonia
}

\begin{abstract}
Strong erosion of accumulative shores and redistribution of matter has been observed along the practically tideless west coast of Estonia during the last half century. This indicates manifestations of climate change, such as increased storminess and high sea level. The objective of the paper is to presents an analysis of sea level data obtained from the Estonian tide gauges over the period 1842-2008 and to discuss the results of a hindcast simulation of wave conditions in the fetch-limited nearshore location of West Estonia for the period 19662006. After adjusting the historical sea level time series to take into account land uplift, the series of mean sea level display an upward trend of between 1.5 and $2.7 \mathrm{~mm} / \mathrm{yr}$, and $4-11 \mathrm{~mm} / \mathrm{yr}$ for annual maximum sea levels. The results for wave climate show some quasi-periodic cycles, including a rise in mean wave height in the 1970s and 1980s, and decrease since 1990. Although both the average wind speed and the wave height show a decrease since 1990s, the annual sea level maxima, as well as the wave maxima continue to increase. Major coastal geomorphic changes seem to occur precisely as a combined result of such relatively infrequent but extreme wintertime wavestorms and storm surges.

Keywords: sea level, wave hindcast, wave climate, trends, storm surges, climate change, Baltic Sea.
\end{abstract}

\section{Introduction}

Estonia lies in the eastern section of the semi-enclosed Baltic Sea (Fig. 1). With amplitudes of $\mathrm{M} 2$ and $\mathrm{K} 1$ waves measuring less than $5 \mathrm{~cm}$, the main 
hydrodynamic agents acting on seashores are waves and meteorologically forced currents and sea level variations [1]. The frequent occurrence of cyclones passing from west to east, and their corresponding changes in wind direction and speed [2], create considerable sea level fluctuations in some suitably exposed bays [3]. While more than $95 \%$ of the sea level data falls within the range of -50 and $+60 \mathrm{~cm}$ in relation to the Kronstadt zero benchmark (which is nearly equal to the long-term mean sea level for the Estonian coast), there are a few exceptional (up to $275 \mathrm{~cm}$ ) storm surges on record [4]. Also, the coastal sea near the islands of Saaremaa and Hiiumaa has the roughest wave regime in Estonian coastal waters, where wave heights can reach 9-10 $\mathrm{m}$ [5].

Some geomorphically interesting sections of the coast lie there, where vitalization of shore processes and redistribution of sediment has been observed during the last decades [6,7]. Illustrious changes in shoreline positions have occurred in the accumulative gravel spits, such as at Küdema (Fig. 1b) [8] and Cape Kelba (Fig. 1c). The coastal formations of the Kelba Spit have been under investigation since the 1960s. The spit is mainly comprised of granite shingles and pebbles, and the beach ridges of different age reach $3.8 \mathrm{~m}$ above sea level [7]. The recent documentation of shoreline positions show that elongations of such spits occur by gradual formation of new accumulative beach ridges, and most probably, during strong storms $[1,4]$.

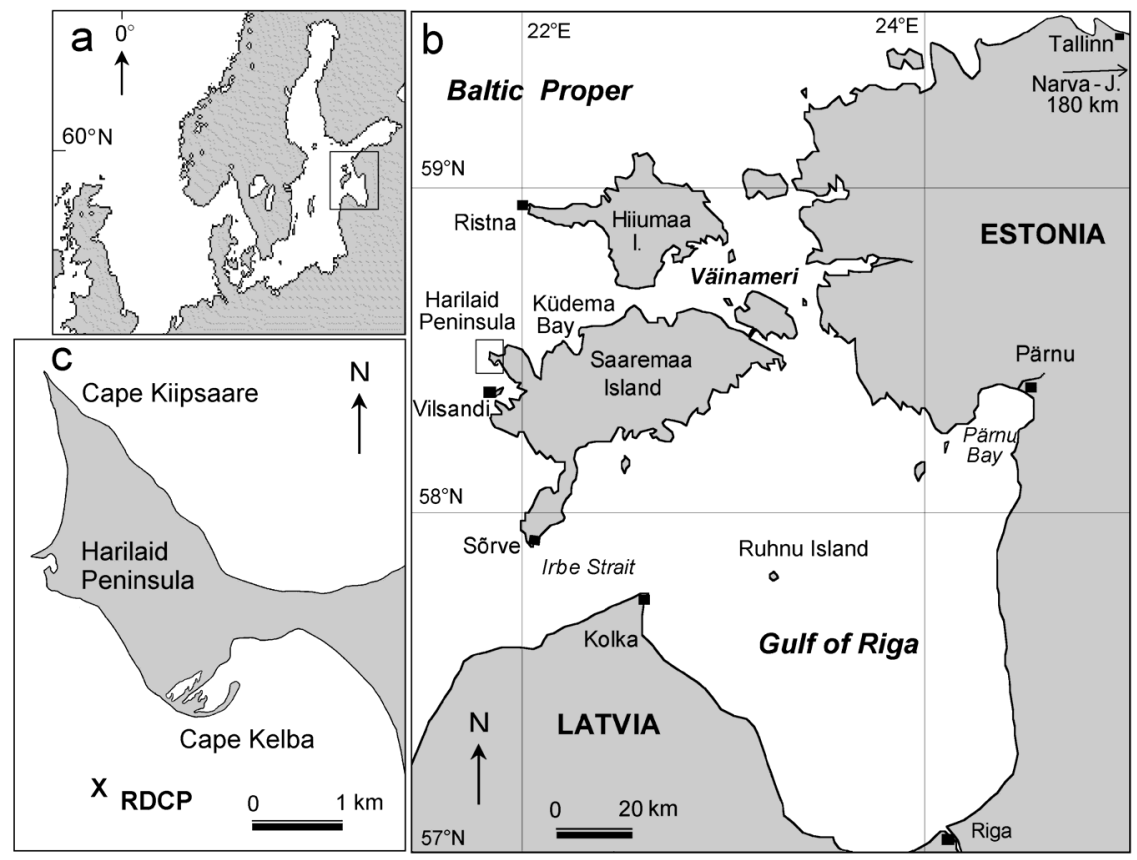

Figure 1: $\quad$ Map of the study area. The location of wave measurements and hindcast is marked with RDCP on (c). 
As the coastal section under study is exposed to the Baltic marine winds, it can be hypothesized that changes in the wind [9], wave [10], and sea level regime are probably reflected in the historical changes in shoreline position and contour. A question arises: is there something particular to the recent developments in sea level and wave regimes that can explain the intensified coastal geomorphic processes in the study area?

The objectives of the paper are (1) to investigate the long-term changes both in mean water level and in extreme sea level events in the Estonian coastal sea; (2) to discuss, based on wave hindcast for 1966-2006, recent changes in mean and extreme wave properties along the western coast of Estonia; and (3) to analyse the relationships between the wind and wave climate, sea level regime and coastal processes.

\section{Material and methods}

\subsection{Data sets and statistical methods for sea level and winds}

The Estonian Meteorological and Hydrological Institute (EMHI) currently operates 21 meteorological stations and 12 tide gauges. Most of the tide gauges are equipped with tide poles and have a sampling frequency of 2 or 3 times a day. Automatic tide gauges of the EMHI, which provide hourly data, are located at Pärnu, Narva-Jõesuu and Ristna (Fig. 1). In Tallinn, the capital city of Estonia, regular sea level measurements started in 1809. The near continuous data sets are available from 1842, but the measurements were discontinued in 1996 due to construction work at the Tallinn Port. We used the data on monthly mean and extreme sea levels up to 2008 from these four stations. They represent relative sea level values in regard to the Kronstadt datum and are based, since 1951, on hourly measurements. The monthly values for earlier periods were obtained on the basis of daily data.

Data about land uplift for the studied stations was taken from the map compiled on the basis of the precise levellings in 1933-1943, 1956-1970 and 1977-1985 [11]. The radial crustal movements in Estonia are mainly influenced by regional Fennoscandian postglacial rebound and the uplift rates vary between 0.5 and $2.8 \mathrm{~mm} / \mathrm{yr}$ along the Estonian coast. Tendencies in time series were analysed using linear regression analysis. A trend slope indicates a mean change per year, the change by trend line is calculated by multiplying the slope by the number of years.

For supplying the wave model with wind speed and direction, we acquired data from the Vilsandi meteorological station. This is the closest station to the calibration site for our wave study, just $7 \mathrm{~km}$ south of the Harilaid Peninsula (Fig. 1b). The station is on the western coast of the island. It has the most open location of all the Estonian weather stations, and satisfactorily represents both the scalar and the directional properties of the marine wind regimes in the northern Baltic Proper [12]. The wind data consisted primarily of hourly measurements from December 2006 until May 2007, which were used for the wave model calibration in relation to special wave measurements [1]. Then, all 
the historical wind data since 1966, available in digital form with a time interval of 3 hours, were used for the long-term hindcast of waves. The wind has been measured with "weathercocks" (wind vanes of Wild's design) in 1966-1976, automatic anemorhumbometers in 1976-2003, and MILOS-520 automatic weather complexes since September 2003. The older data in the database has been slightly corrected for homogeneity [13].

\subsection{Wave measurements and modelling}

The long-term calculations of wave parameters with the use of the SMB model were performed for the coastal region of Vilsandi-Harilaid (Fig. 1b). The location of the case study of hydrodynamic measurements and modelling was 1$1.5 \mathrm{~km}$ off the coast of the Harilaid Peninsula (Fig. 1c). The SMB-model, also called the significant wave method, is based on the fetch-limited equations of Sverdrup, Munk, and Bretschneider [14-16]. It calculates the significant wave height, wave period and wavelength for the chosen location under the assumption that the wind properties are constant over the entire fetch area. As strong winds are mostly homogeneous in the Baltic Proper [12] and both the reaction and memory time of a large part of the wave fields in this basin are relatively short [5], such simple models are valuable tools for rapid estimates of the wave statistics and the first approximation of the wave time series.

For comparison and calibration of the SMB-model, an oceanographic measuring complex RDCP-600 from AADI Aanderaa Instruments was deployed at a seabed depth of $14 \mathrm{~m}$ between 20 December 2006 and 23 May 2007 [1]. During this 5-month comparison period, the SMB model reproduced the wave parameters at the single point with acceptable accuracy. The model output required very moderate calibration to yield as high correlation coefficient as 0.88 , low RMSE (0.233) and nearly equal average and maximum values of calculated and measured wave properties [13]. The calibrated model was further used in multiyear (1966-2006) wave hindcast. An additional comparison of hindcasts for the year 1996 between the SMB model and $3^{\text {rd }}$ generation WAM model showed that considering the limitations of such SMB-type models, it performed surprisingly well and can be used for local long-term hindcasts [17].

\section{Results and discussion}

\subsection{Decadal variations in mean and extreme sea level}

With regard to the mean relative sea level of a location, the main factors influencing its variations are: global sea level change, the land uplift or subsidence and changes in the water balance of the particular sub-basin. Time series of annual mean sea levels show mostly increasing tendencies in Estonia (Fig. 2, Table 1). After adjusting these rates to account for local land uplift rates, we calculated sea level rise rates of $1.5 \mathrm{~mm} / \mathrm{yr}$ in Tallinn (1842-1995), $1.7 \mathrm{~mm} / \mathrm{yr}$ in Narva-Jõesuu (1899-2008), $1.7 \mathrm{~mm} / \mathrm{yr}$ in Ristna (1950-2008) and $2.7 \mathrm{~mm} / \mathrm{yr}$ in Pärnu (1924-2008). The trend estimates for annual maximum sea levels are much higher and vary between 4 and $10 \mathrm{~mm} / \mathrm{yr}$ for different tide 
gauges and study periods (Fig. 3, Table 1). However, moving averages of annual mean sea level series show 30-40 year cycles (Fig. 2). These cycles, with amplitudes of about $5 \mathrm{~cm}$, can influence linear trend estimates, which slightly depend on the period chosen.

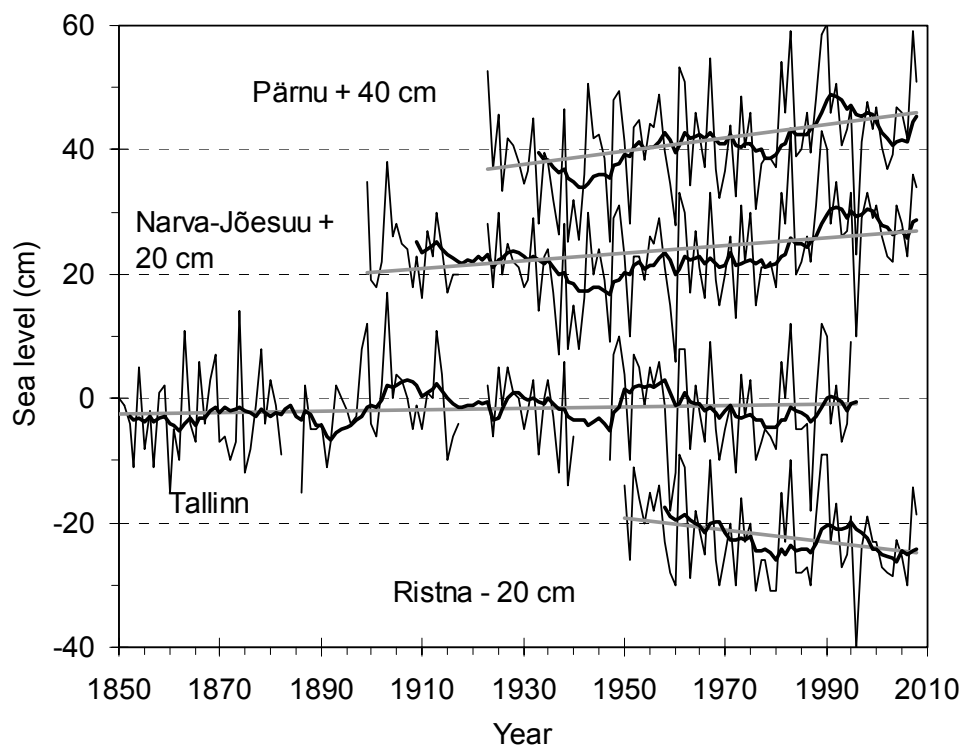

Figure 2: $\quad$ Decadal variations in annual mean relative sea levels (until 2008) together with 11-year moving averages and linear trendlines at four Estonian tide gauges. The series are not corrected with land uplift rates, which are different in different gauges (see Table 1). The different series are shifted in relation to each other for clarity.

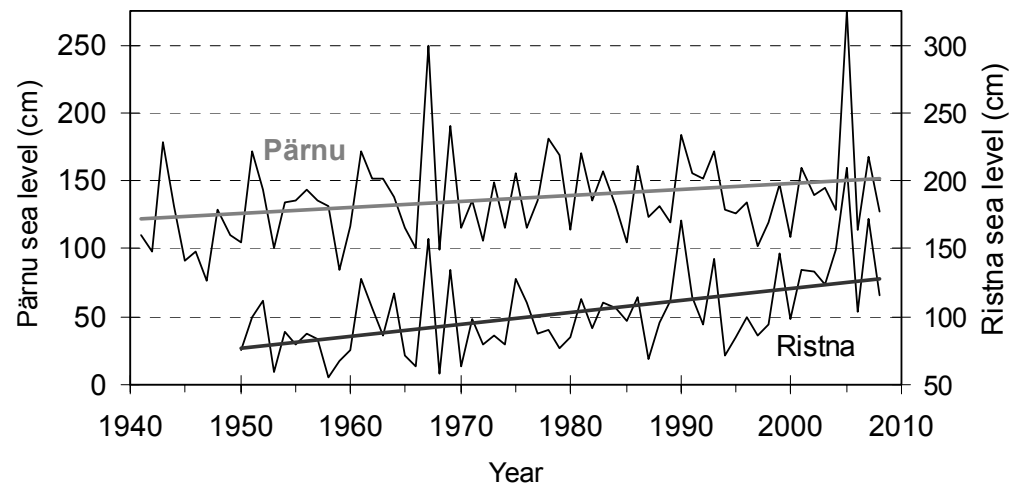

Figure 3: Decadal changes of annual maximum sea levels at Ristna and Pärnu (excerpt). 
Table 1: $\quad$ Trends for annual minimum, maximum and mean sea levels in different tide gauges and study periods. Actual sea level (ASL) rise rate is a sum of rates of relative sea level (RSL) and local land uplift $(\mathrm{mm} / \mathrm{yr})$.

\begin{tabular}{|l|l|l|ll|ll|ll|}
\hline \multirow{2}{*}{$\begin{array}{c}\text { Tide } \\
\text { gauge }\end{array}$} & Period & Uplift & \multicolumn{2}{c|}{ Min } & \multicolumn{2}{c|}{ Max } & \multicolumn{2}{c|}{ Mean } \\
\hline Pärnu & $1924-2008$ & 1.5 & 1.6 & 3.1 & 2.9 & 4.4 & 1.2 & 2.7 \\
& $1946-2008$ & 1.5 & 2.1 & 3.6 & 4.2 & 5.8 & 1.1 & 2.6 \\
\hline Ristna & $1950-2008$ & 2.6 & -0.2 & 2.4 & 8.8 & 11.4 & -0.9 & 1.7 \\
\hline Narva-J. & $1899-2008$ & 0.5 & 0.4 & 0.9 & 4.3 & 4.8 & 0.6 & 1.1 \\
& $1946-2008$ & 0.5 & 1.0 & 1.5 & 7.1 & 7.6 & 1.7 & 2.2 \\
\hline Tallinn & $1899-1995$ & 1.8 & 0.1 & 1.9 & 1.9 & 3.7 & -0.3 & 1.5 \\
& $1947-1995$ & 1.8 & -1.0 & 0.8 & 3.9 & 5.7 & -0.3 & 1.5 \\
\hline
\end{tabular}

Positive sea level trends in annual time series appear due to the more positive trends in winter (December to March) sea level, since during the summer such trends are less steep or even negative (Fig. 4b). The significantly higher mean sea level rise in winter correlates with increased local storminess during the same months and with the greater intensity of westerlies in winter, as described by the NAO-index (Fig. 4c) [2, 18]. The existence of this type of time variable relationship between sea level and atmospheric circulation is common for other Baltic Sea level data sets as well [19].

Except in Pärnu, our mean sea level rise estimates (Table 1) are roughly equal to or insignificantly higher than the most recent global sea level rise estimates, which are around $1.7 \mathrm{~mm} / \mathrm{yr}$ according to [20]. The excessive Pärnu sea level rise rate (Table 1, Figs. 2,3) over the global estimates can be explained by a mechanism, which was explained in a hydrodynamic modelling experiment [3]. These results indicate that in case of an obvious decadal trend in wind conditions the sea level change rates of a semi-enclosed basin may deviate from the global estimates. A positive trend in wind speed and storminess should result in a steeper than average sea level trend on the windward side and one that is less steep on the leeward side. Indeed, a clear increase in the westerly wind component occurred between 1950 and 1990 [21, 22]. Although further increase in westerly winds is anticipated, it is also possible that the increase in westerlies and winter NAO in 1950-90 could be followed by a relative increase in easterlies [23].

Trend analyses have shown that storm surges are becoming higher both in Estonia [18 and in Western Europe [23]. Pärnu sea level records (Figs. 2, 3, 4a) identify 30 individual events higher than the critical value of $150 \mathrm{~cm}, 24$ of which occurred between the months of October-March. The two highest sea level events off the Estonian coast (since 1923) were both registered at Pärnu: $253 \mathrm{~cm}$ on 19 October 1967 and $275 \mathrm{~cm}$ on 9 January 2005. At the same time, the average wind speed has probably decreased over the last 50 years in Estonia (Fig. 5a). However, it is important that westerlies have increased and easterlies 
decreased. Also, both frequency and intensity of high wind speed events have increased (Fig. 5a) [13].

\subsection{Decadal variations in wave condition}

The mean wave heights and wave periods show quasi-periodic cycles with the last high stage in 1980-1995 and a slightly decreasing overall trend $-0.001 \mathrm{~m}$ per year in 1966-2006 (Fig. 5).
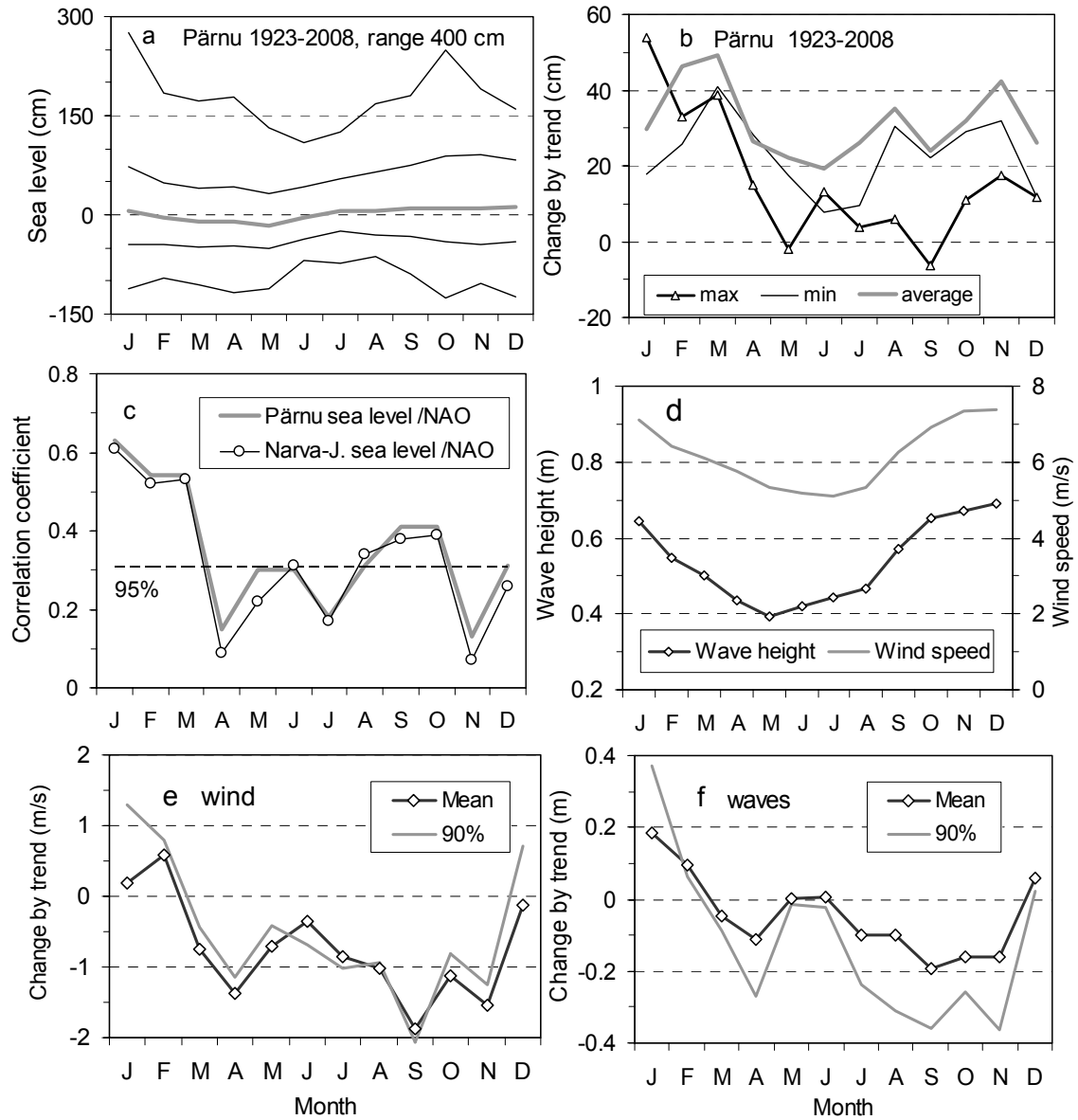

Figure 4: Seasonal variations in annual sea level statistics (a; lines from top: absolute maximum, average maximum, mean, average minimum and absolute minimum), sea level changes by trend over the period (b), correlations with atmospheric circulation data (c), mean wave heights and wind speeds (d), changes by trend in wind speed (e) and wave statistics (f) over the period 1966-2006. 

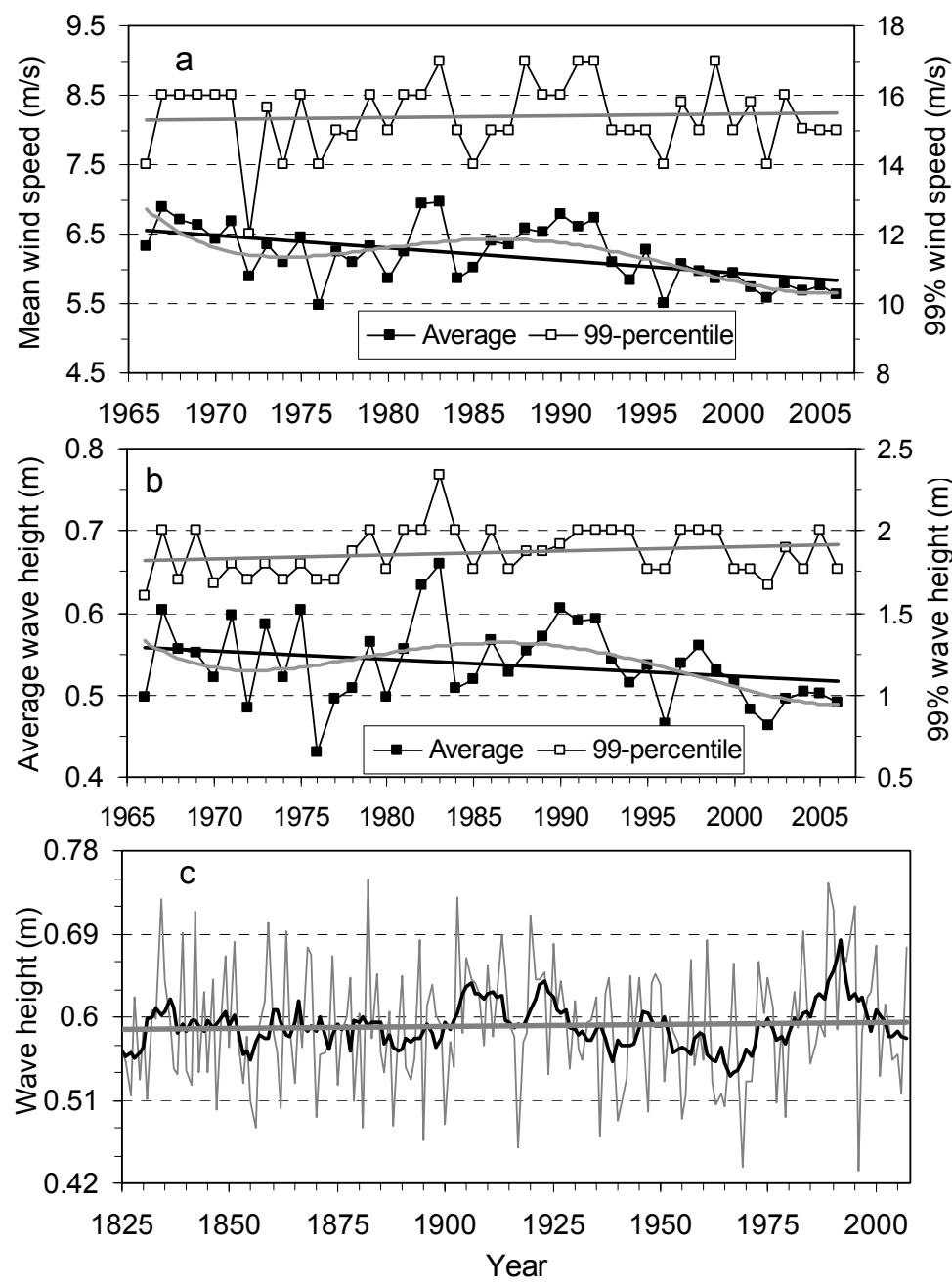

Figure 5: Decadal variations in averages and 99-percentiles of annual samples for winds (a) and waves (b). NAO-based reconstruction of wintertime significant wave heights along West Estonian coast (c).

However, the trends of wave properties are different in different months (Fig. 4f). For example, the December to March subset of mean wave heights shows an increasing trend of $0.0017 \mathrm{~m}$ per year. On the basis of annual series of the 90 and 99 percentiles, as well as annual maxima, the trend is clearly increasing (Fig. 5b) [13]. Thus, the trends in the average properties of wave fields and in extreme wave conditions are different along the western coast of Estonia.

Such tendencies in wave heights and variability seem to correspond to the long-term tendencies in mean and extreme wind speeds at the Vilsandi 
meteorological station (Figs. 4d,5). The time series of waves are strongly correlated with wind speed, the W-E wind component, and the NAO index (Table 2). Generally, the Iceland-Gibraltar version of the NAO index [21] is expected to best describe the variations in the Estonian climate [2]. Since monthly NAO data have been available since the 1820s (and even closely similar historical wind data does not exist), we tried to reconstruct wave conditions at the selected location back to $19^{\text {th }}$ century. The highest correlation $(r=0.72)$ between the NAO-index and the wave data in 1966-2006 was found from December to March. Based on this regression, a reconstruction of wave conditions is shown in Fig. 5c. There, an increase in wintertime wave activity is visible in 1970s, 1980s and 1990s. Quite possibly, the observed "vitalization of shore processes" falls into this period. But we cannot assume that this tendency will last forever (Fig. 5c).

Also we must stress here: though statistically significant, the outcome is strongly dependent on the quality of the NAO reconstructions and the NAObased reconstruction of past (1825-2006) wave climates should be treated with the utmost caution. Although the wave conditions in fetch-limited areas are supposed to be highly site-dependent, some recent changes in regional wind climate and cyclone trajectories $[2,22]$ may have had a similar effect on wave conditions in different, though not necessarily adjacent marine areas. The main factor seems to be the similar exposure of a location to a certain direction, the importance of which in wind distribution is changing. For example, high wave events increased during 1958-1992 in the SE section of the North Sea along the windward coasts of Germany, Netherlands and Denmark [24] under conditions of increased westerlies and cyclonic activity [22, 25].

\subsection{Relationships between atmospheric circulation, local wind climate, hydrodynamic regime and coastal geomorphic processes}

Wind speed, storminess, sea level variations and wave statistics are correlated to each other and to the NAO-index on the windward coast of Estonia (Table 2) $[2,18]$.

Table 2: $\quad$ Correlation coefficients between some atmospheric forcing factors and selected average and extreme wave and sea level statistics (annual data samples 1966-2006).

\begin{tabular}{|l|c|c|c|c|r|}
\hline \multirow{2}{*}{} & \multicolumn{3}{|c|}{ Wave statistics } & \multicolumn{2}{c|}{ Ristna sea level } \\
\cline { 2 - 6 } & Av. & $90 \%$ & $99 \%$ & Av. & Max. \\
\hline NAO, months I-XII & 0.48 & 0.35 & 0.41 & 0.56 & 0.18 \\
\hline NAO, months VIII-II & 0.61 & 0.50 & 0.43 & 0.63 & 0.11 \\
\hline Wind speed modulus & 0.87 & 0.52 & 0.38 & 0.63 & -0.10 \\
\hline Wind speed 90\%-ile & 0.76 & 0.65 & 0.56 & 0.53 & 0.15 \\
\hline Wind speed 99\%-ile & 0.67 & 0.56 & 0.57 & 0.52 & 0.18 \\
\hline W-E wind component & 0.85 & 0.79 & 0.60 & 0.70 & 0.23 \\
\hline S-N wind component & 0.11 & -0.02 & 0.07 & 0.09 & 0.12 \\
\hline
\end{tabular}




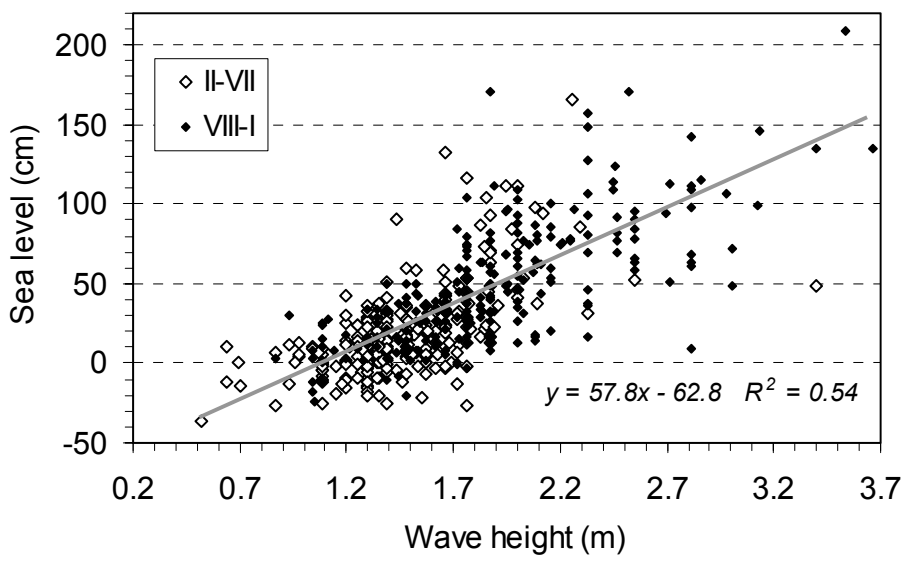

Figure 6: Dependence between monthly maximum sea levels at Ristna and corresponding monthly $99 \%$-ile wave heights near Harilaid from 1966 to January 2007 grouped by two half years (II-VII and VIII-I; the regression is given for the whole data set).

The increase in $\mathrm{W}$ and $\mathrm{S}$ winds and the decrease in $\mathrm{N}$ and $\mathrm{E}$ winds imply certain shifts in the air-pressure systems and cyclone trajectories above the Baltic Sea; this is also expressed by recent tendencies in the NAO-index $[2,21]$.

Interestingly enough, neither the mean wind speed (Fig. 5a), mean wave heights (Fig. 5b), nor mean sea level regime (Fig. 2) had changed in a way that can explain all the documented "vitalization" of shore processes. The explanation obviously lies behind the extreme events (Figs. 3, 5), which have become both more frequent and more prominent. Also, such events are not distributed randomly over the seasonal cycle (Fig. 4). As a rule, powerful wave storms occur in autumn or winter months, when also the sea level is higher (Fig. 6). As wave energy is roughly proportional to the wave height squared, the energy of extremely strong storms and its impact on the coastal zone are many times higher than that of ordinary storms. Compared to the relatively very small energies of typical conditions, that energy is released in a broader zone and 13 meters above the average sea level (Fig. 6). On the other hand, small velocities below a certain threshold value are not able to erode, suspend, and transport sediment at all. They are "wasted" in geomorphic point of view.

In Estonia, the coastal processes in the past were largely influenced by isostatic land uplift (1-3 mm/yr) and marine regression. By now it is entirely compensated by sea level rise (Table 1). Despite some visible quasi-periodic cycles in climatic variables, in a longer perspective, the anticipated warmer winters, higher mean and extreme sea levels, more frequent strong storms, decreasing sea ice extent and duration $[2-6,23]$ are expected to intensify the shore processes in the future. 


\section{Conclusions}

Although the mean properties of wind speed, wave heights and sea level have not changed recently in a way that can explain the observed intensified shore processes, the extreme statistics of these parameters all show significant increases. Powerful wave storms occur in autumn or winter months, when also the sea level is higher. Major coastal geomorphic changes occur precisely as a combined result of such relatively infrequent but extreme wintertime wavestorms and storm surges. As wave energy is roughly proportional to the wave height squared, the energy of extremely strong storms and its impact on the coastal zone can be increasingly higher.

\section{Acknowledgements}

The study was supported by the Estonian Science Foundation through grants No. 7609 and 7564, and target financed theme SF0180104s08.

\section{References}

[1] Suursaar, Ü., Jaagus, J., Kont, A., Rivis, R. \& Tõnisson H., Field observations on hydrodynamic and coastal geomorphic processes off Harilaid Peninsula (Baltic Sea) in winter and spring 2006-2007. Estuarine Coastal and Shelf Science, 80, pp. 31-41, 2008.

[2] Jaagus, J., Post, P. \& Tomingas, O., Changes in storminess on the western coast of Estonia in relation to large-scale atmospheric circulation. Climate Research, 36, pp. 29-40, 2008.

[3] Suursaar, Ü. \& Kullas, T., Influence of wind climate changes on the mean sea level and current regime in the coastal waters of west Estonia, Baltic Sea. Oceanologia, 48, pp. 361-383, 2006.

[4] Tõnisson, H., Orviku, K., Jaagus, J., Suursaar, Ü., Kont, A. \& Rivis, R., Coastal Damages on Saaremaa Island, Estonia, Caused by the Extreme Storm and Flooding on January 9, 2005. Journal of Coastal Research, 24, pp. 602-614, 2008.

[5] Broman, B., Hammarklint, T., Rannat, K., Soomere, T. \& Valdmann, A., Trends and extremes of wave fields in the northern part of the Baltic Proper. Oceanologia, 48 (s), pp. 165-184, 2006.

[6] Orviku, K., Jaagus, J., Kont, A., Ratas, U. \& Rivis, R., Increasing activity of coastal processes associated with climate change in Estonia. Journal of Coastal Research, 19, pp. 364-375, 2003.

[7] Rivis, R., Changes in shoreline positions on the Harilaid Peninsula, West Estonia, during the 20th century. Proc. Estonian Acad. Sci. Biol. Ecol., 53, pp. 179-193, 2004.

[8] Suursaar, Ü., Tõnisson, H., Kullas, T., Orviku, K., Kont, A., Rivis, R. \& Otsmann, M., A study of hydrodynamic and coastal geomorphic processes in Küdema Bay, the Baltic Sea. Coastal Engineering VII, eds. C.A. Brebbia \& C. Cunha, WIT Press: Southampton, Boston, pp. 187-196, 2005. 
[9] Alexandersson, H., Schmidt, T., Iden, K. \& Tuomenvirta, H., Long-term variations of the storm climate over NW Europe. The Global Atmos. Ocean. Syst., 6, pp. 97-120, 1998.

[10] WASA Group, Changing waves and storms in the Northeast Atlantic? Bull. Am. Meteorol. Soc., 79, pp. 741-760, 1998.

[11] Vallner, L., Sildvee, H. \& Torim, A., Recent crustal movements in Estonia. J. Geodyn., 9, pp. 215-223, 1988.

[12] Soomere, T., Extreme wind speeds and spatially uniform wind events in the Baltic Proper. Proc. Estonian Acad. Sci. Eng., 7, pp. 195-211, 2001.

[13] Suursaar, Ü. \& Kullas, T., Decadal variations in wave heights off Cape Kelba, Saaremaa Island, and their relationships with changes in wind climate. Oceanologia, 51, pp. 39-61, 2009.

[14] Seymour, R.J., Estimating wave generation in restricted fetches. J. ASME WW2, May 1977, pp. 251-263, 1977.

[15] U.S. Army Coastal Engineering Research Center, Shore Protection Manual, Vol.1, Third Ed., U.S. Govt. Printing Office, Washington D.C., $719 \mathrm{pp}, 1984$.

[16] Huttula, T., Suspended sediment transport in Lake Säkylän Pyhäjärvi, Aqua Fennica, 24, pp. 171-185, 1994.

[17] Räämet, A., Suursaar, Ü., Kullas, T. \& Soomere, T., Reconsidering uncertainties of wave conditions in the coastal areas of the northern Baltic Sea. Journal of Coastal Research, SI 56, 2009. (in press).

[18] Suursaar, Ü. \& Sooäär J., Decadal variations in mean and extreme sea level values along the Estonian coast of the Baltic Sea. Tellus A, 59, pp. 249 260, 2007.

[19] Wakelin, S.L., Woodworth, P.L., Flather, R.A. \& Williams, J.A., Sea-level dependence on the NAO over the NW European Continental Shelf. Geophys. Res. Lett., 30, Art. No. 1403, 2003.

[20] Church, J.A. \& White, N.J., A 20th century acceleration in global sea-level rise. Geophys. Res. Lett., 33, L01602, 2006.

[21] Jones, P.D., Jónsson, T. \& Wheeler, D., Extension to the North Atlantic Oscillation using early instrumental pressure observations from Gibraltar and South-West Iceland. Int. J. Climatol., 17, pp. 1433-1450, 1997.

[22] Siegismund, F. \& Schrum, C., Decadal changes in the wind forcing over the North Sea. Climate Research, 18, pp. 39-45, 2001.

[23] Lowe, J.A., Gregory, J.M. \& Flather, R.A., Changes in the occurrence of storm surges around the United Kingdom under a future climate scenario using dynamic storm surge model driven by the Hadley Centre climate models. Climate Dynamics, 18, pp. 179-188, 2001.

[24] Weisse, R. \& Günther, R., Wave climate and long-term changes for the Southern North Sea obtained from a high-resolution hindcast 1958-2002. Ocean Dynamics, 57, pp. 161-172, 2007.

[25] Bauer, E., Interannual changes of the ocean wave variability in the North Atlantic and in the North Sea. Climate Research, 18, pp. 63-69, 2001. 